\title{
TŁUMACZENIE AMERYKAŃSKICH SITCOMÓW: PIOSENKI JAKO WYZWANIE DLA TŁUMACZA
}

DOl: http://dx.doi.org/10.12775/RP.2018.011

\begin{abstract}
Zarys treści: Przedmiotem niniejszej analizy jest rola piosenek w amerykańskich sitcomach oraz możliwe problemy tłumaczeniowe związane z przekładem modyfikacji piosenek i nawiązań do znanych utworów muzycznych. Część teoretyczna poświęcona jest sitcomowi jako gatunkowi tekstu oraz ogólnym aspektom tłumaczenia piosenek. Następnie omówiono fragmenty zaczerpnięte z seriali „Friends”, „The Big Bang Theory”, „How I Met Your Mother” i z ich oficjalnych telewizyjnych tłumaczeń na język polski i niemiecki. Artykuł dowodzi, że w przypadku tłumaczenia sitcomów nieuniknione jest tłumaczenie piosenek oraz że w tym gatunku tłumaczenie piosenek stanowi równocześnie tłumaczenie humoru.
\end{abstract}

Słowa kluczowe: tłumaczenie audiowizualne, sitcom, tłumaczenie humoru, piosenki

\section{Wstęp}

Drzedmiotem niniejszego artykułu jest jeden z elementów charakterystycznych amerykańskiego sitcomu, jaki stanowi używanie piosenek oraz nawiązań do nich w celu osiągnięcia efektu humorystycznego, czyli rozbawienia widzów. Aby ustalić rolę piosenek w tym gatunku przeanalizowano odcinki kilku amerykańskich sitcomów („Friends”, „Frasier”, „Will \& Grace”, „How I Met Your Mother”, „Two and a Half Men”, „The Big Bang Theory”) pod kątem występowania w nich mówionych bądź śpiewanych, oryginalnych bądź cytowanych tekstów piosenek. Badanie wykazało, że we wszystkich tych serialach pojawiają się nie tylko nawiązania do znanych utworów wplecione w dialogi, lecz również covery przebojów oraz oryginalne piosenki wykonywane przez aktorów. Powtarzalność tego elementu pozwala stwierdzić, że podczas tłu- 
maczenia amerykańskich sitcomów należy liczyć się również z koniecznością dokonania przekładu piosenki. W przedstawianym artykule zostanie omówiony fenomen piosenek $\mathrm{w}$ sitcomach oraz wybrane aspekty tłumaczenia piosenek w kontekście utworów audiowizualnych. Następnie zaprezentowana zostanie krótka analiza kilku przykładów modyfikacji piosenek i nawiązań do tekstów piosenek w dialogach jako namiastka tego, z czym muszą mierzyć się tłumacze. Jako źródło przykładów posłużyły trzy z ww. sitcomów, a mianowicie „Friends” (emitowany w latach 1994-2004, stworzony przez Davida Crane’a i Martę Kauffman, polski tytuł „Przyjaciele”), „How I Met Your Mother” (emitowany w latach 2005-2014, stworzony przez Cartera Baysa i Craiga Thomasa, polski tytuł „Jak poznałem waszą matkę") oraz „The Big Bang Theory" (emitowany od 2007 roku, stworzony przez Chucka Lorre'ego i Billa Prady'ego, polski tytuł „Teoria wielkiego podrywu”). Fragmenty oryginalnych dialogów zostały zestawione $\mathrm{z}$ oficjalnymi telewizyjnymi tłumaczeniami na język polski (w wersji lektorskiej) i na język niemiecki (w wersji z dubbingiem). Celem artykułu jest zobrazowanie roli piosenek w sitcomach i zarysowanie możliwych problemów tłumaczeniowych związanych z przekładem modyfikacji piosenek i nawiązań do nich.

\section{Rola muzyki w sitcomach}

Sitcom to telewizyjny gatunek komediowy, którego odcinek trwa ok. $30 \mathrm{mi}$ nut, przedstawia oddzielny wątek, ma zazwyczaj szczęśliwe zakończenie i w którym te same postaci pojawiają się w tej samej scenerii, a nagrany śmiech publiczności jest częścią jego ścieżki dźwiękowej (Mintz 1985: 115). Najważniejszą cechą sitcomu jest komizm, który pociąga za sobą odpowiednią kreację postaci, sposób ustawienia kamery itd. (Mills 2009: 49). Ważną rolę w sitcomie pełni także muzyka. Mills (2009: 38) w swojej charakterystyce tego gatunku wskazuje na to, że czołówce każdego z odcinków towarzyszy wesoły utwór przewodni (np. Przyjaciele: „'lll Be There For You” - The Rembrandts, „Jak poznałem waszą matkę”: „Hey Beautiful” - The Solids) oraz na to, że krótka melodia jest używana do zasygnalizowania przejścia między scenami. Na tym jednak nie kończy się rola muzyki w tym gatunku.

Piosenki oraz nawiązania do znanych utworów używane są w sitcomach bardzo często jako narzędzie do osiągnięcia efektu humorystycznego, czyli innymi słowami do wywołania śmiechu publiczności zgromadzonej przed telewizorami. Wprawdzie, jak podkreśla Dore (2008: 18 ff.), związek pomiędzy humorem a śmiechem jako reakcją psychologiczną i fizjologiczną pozostaje kwestią sporną dla badaczy humoru, to jednak w codziennym rozumowaniu pojęcie 
humor nierozerwalnie kojarzy się ze śmiechem, co wynika np. z definicji wspomnianego leksemu („przedstawienie czegoś w zabawny sposób”) oraz powiązanej definicji przymiotnika zabawny („,wywołujący śmiech"2) sformułowanych w „Słowniku Języka Polskiego” PWN. Problematyczność definiowania humoru i jednoznacznego przesądzania o zabawności dowcipów wiąże się przede wszystkim z tym, jak wysoce indywidualną kwestią jest poczucie humoru. Nie sposób nie zgodzić się ze stwierdzeniem Dore (2008: 16), że humor jest „konceptem względnym, specyficznym dla jednostek i zależnym od kultury i czasu" (tłumaczenie - K.P.). W przypadku sitcomów widzowie otrzymują jednak od twórców sygnał na temat zabawnego charakteru dialogów w postaci nagranego śmiechu publiczności. Ten fragment ścieżki dźwiękowej pozwala definitywnie osądzić, celem których wypowiedzi jest osiągnięcie efektu humorystycznego ${ }^{3}$.

Piosenki, czyli „kompozycje ze słów i muzyki” przekazujące komunikat w sposób werbalny i niewerbalny (Low 2005: 189, tłumaczenie - K.P.), wywołują w sitcomach efekt humorystyczny na takiej samej zasadzie jak inne dowcipy. Smith (1999: 14 ff.) wymienia wśród cech charakterystycznych dowcipów niespójność, element zaskoczenia, odniesienie do prawdziwego życia, agresywność i zwięzłość. W tych samych kategoriach można analizować piosenki. Utwory wplecione $\mathrm{w}$ fabułę poszczególnych odcinków są oczywiście osadzone w kulturze wyjściowej utworu i w związku z tym przedstawiają dowcipy kulturowe w ujęciu Raphaelson-West (1989: 132 ff.) i trzecią sytuację opisaną w typologii komizmu Kalagi (1997: 12). Ten typ komizmu „wynika $\mathrm{z}$ modelu świata, [...] [który] jest nie tyle bezpośrednio komunikowany przez język (jako nośnik), co jest w języku zawarty i wynika z języka" (Kalaga 1997: 12) i ,jest [zatem] wynikiem konotacyjnych skojarzeń charakterystycznych dla danego kręgu kulturowego" (Kalaga 1997: 14). Istotny jest tutaj fakt, że utwory pojawiające się $\mathrm{w}$ amerykańskich sitcomach niekoniecznie muszą być znane docelowym odbiorcom z kultury polskiej czy niemieckiej. Tak jak w kontekście tłumaczenia gier słów opisywanego przez Chiaro (1992: 10 ff.), tak i tutaj należy się odnieść do „konceptu wspólnej wiedzy”.

Piosenki mogą być wykorzystywane w sitcomach na różne sposoby. Mogą zostać użyte w oryginale lub jako covery wykonane przez aktorów. Bardzo często tworzone są także modyfikacje znanych przebojów, które w spo-

${ }^{1}$ Słownik języka polskiego, https://sjp.pwn.pl/szukaj/humor.html (dostęp: 20 listopada 2017 r.).

${ }^{2}$ Słownik języka polskiego, https://sjp.pwn.pl/szukaj/zabawny.html (dostęp: 20 listopada 2017 r.).

${ }^{3}$ O roli nagranego śmiechu publiczności piszą np. Mills (2009: 16-17, 42) i Savorelli (2010: $22,32)$. 
sób mniej lub bardziej oczywisty nawiązują do oryginałów. Oprócz tego, w dialogi mogą być również wplecione nawiązania do tekstów znanych utworów. Nietrudno jest znaleźć przykłady na wspomniane zastosowania muzyki. Utworami użytymi w oryginale 4 są np.: „You Give Love a Bad Name” - Bon Jovi („Jak poznałem waszą matkę”: $1 \times 11$ ), „Footloose” - Kenny Loggins („Will \& Grace”: 5×02), „Darlin” - Beach Boys („Teoria wielkiego podrywu”: $9 \times 10)$, „With or without you” - U2 („Przyjaciele”: $2 \times 08$ ), a coverami wykonanymi przez aktorów: „Endless Love” - Lionel Richie („Przyjaciele”: $3 \times 08$ ), „Sweet Caroline” - Neil Diamond („Teoria wielkiego podrywu”: $5 \times 21$ ), „Hey Ya!” - OutKast („Will \& Grace”: 6×18), „Great Balls of Fire” - Jerry Lee Lewis („Frasier”: 2×17), „Bohemian Rhapsody” - Queen („Dwóch i pół”: $3 \times 21$ ), „La Vie en rose” - Édith Piaf („Jak poznałem waszą matkę”: 9×16).

W sitcomach pojawiają się ponadto oryginalne piosenki, które zostały skomponowane i napisane na potrzeby danego serialu, i zaśpiewane przez aktorów. W „Przyjaciołach” wykonano ponad 40 takich utworów (np. „Smelly Cat" - w wielu odcinkach, „Snowman” - odc. $1 \times 10$ ), w „Jak poznałem waszą matkę" - ponad 20 (np. „Let's Go to the Mall” - odc. $2 \times 09$, „Sandcastles in the Sand” - odc. $3 \times 16$ ); kilka pojawia się również w „Teorii wielkiego podrywu” (np. „If I Didn't Have You” - odc. 7×06, „Thor and Dr. Jones” - odc. 9×04). Liczby te i przykłady wyraźnie pokazują, jak ważnym aspektem tłumaczenia sitcomów jest przekład piosenek.

\section{Tłumaczenie tekstów piosenek}

Wydaje się, że tłumacze mają cztery podstawowe możliwości przy przekładzie piosenek. Mogą przetłumaczyć wyłącznie ich znaczenie, zachowując tym samym ekwiwalencję denotatywną w ujęciu Kollera (2004: 228). Oprócz przełożenia znaczenia dosłownego mogą także odtworzyć formę tekstu piosenki, zachowując zarówno ekwiwalencję denotatywną, jak i formalno-estetyczną (Koller 2004: 252). Mogą również stworzyć tekst docelowy w formie piosenki odbiegającej znaczeniem od oryginału, ale dostosowanej do muzyki. Oczywiście opcją jest też pominięcie śpiewanych fragmentów, co w terminologii Tomaszkiewicz (2004: 72) nazywane jest opuszczeniem i interpretowane jest w zależności od kontekstu, w którym się pojawia albo jako błąd tłumaczeniowy, albo jako technika tłumaczeniowa.

${ }^{4}$ Utwory te nie są zwykłą ścieżką dźwiękową stanowiącą tło dla poszczególnych scen. Stanowią one element dowcipu (dwa pierwsze przykłady) lub ich teksty są ściśle związane z fabułą danego odcinka (kolejne przykłady). 
Biorąc pod uwagę formę piosenek występujących w sitcomach (por. punkt 1), można je z jednej strony traktować jako elementy o silnym nacechowaniu kulturowym i w konsekwencji postrzegać jako elementy obce dla odbiorcy translatu ${ }^{5}$ (np. gdy są odtworzone w oryginale), a $\mathrm{z}$ drugiej jako elementy intertekstowe ${ }^{6}$ (np. gdy nawiązanie do nich stanowi fragment dialo$\mathrm{gu})$. Wśród technik tłumaczeniowych wykorzystywanych w celu przekładu elementów kulturowych Tomaszkiewicz (2006: 155 ff.) wymienia: opuszczenie, bezpośredni transfer, rozwinięcie definicyjne i peryfrazę definicyjną, ekwiwalencję terminologiczną, funkcjonalną i kontekstową, adaptację oraz substytucję za pomocą wyrażeń deiktycznych. Zważając na fakt, jak częstym zjawiskiem są piosenki w sitcomach, opuszczenie jako technika tłumaczeniowa powinno być ostatecznością. Techniczne ograniczenia tłumaczenia audiowizualnego raczej wykluczają rozwinięcie i peryfrazę. Ponieważ w przypadku tekstów piosenek nie chodzi o terminy ani pojedyncze leksemy, nie znajdą tutaj zastosowania także wymienione rodzaje ekwiwalencji ani substytucja. Najbardziej adekwatnymi technikami wydają się zatem być bezpośredni transfer (jeśli piosenki pojawiają się $\mathrm{w}$ sitcomie $\mathrm{w}$ wersji oryginalnej) $\mathrm{i}$ adaptacja (w przypadku modyfikacji i nawiązań).

Stwierdzenie, że jeśli w dialogach pojawiają się nawiązania do utworów muzycznych z kultury wyjściowej, przed przystąpieniem do tłumaczenia należy przeanalizować je tak, jak wszystkie inne aluzje, wydaje się zasadne. Tomaszkiewicz (2006: 176) podkreśla dwa ważne aspekty intertekstowości: rozpoznawalność nawiązania dla odbiorców tekstu docelowego oraz funkcję aluzji w tekście wyjściowym. Jak już wspomniano w punkcie 1, celem użycia w sitcomach piosenek, nawiązań do nich lub ich modyfikacji jest zazwyczaj osiągnięcie efektu humorystycznego. Tłumaczenie piosenek w tym gatunku trzeba zatem postrzegać jako tłumaczenie humoru. Jeśli ograniczenia techniczne nie pozwalają na oddanie w pełni oryginalnego charakteru, powinno się zastosować technikę kompensacji (Tomaszkiewicz 2004: 54; Tomaszkiewicz 2006: 185, 190) i dążyć do osiągnięcia efektu humorystycznego w inny sposób.

Z punktu widzenia muzykologii przy przekładzie tekstów piosenek należy, tak jak przy tłumaczeniu poezji, uwzględnić miarę rytmiczną (Spaeth 1915: 296) i rozłożenie akcentów (Spaeth 1915: 294). Spaeth (1915: 293) twierdzi, że tłumacz utworów muzycznych musi przede wszystkim „osiągnąć

${ }^{5}$ Döring (2006: 20) w swoim zestawieniu elementów kulturowych w filmach wymienia ogólnie muzykę.

${ }^{6}$ Tomaszkiewicz (2006: 180) podaje muzykę jako przykład intertekstowości w filmie „8 kobiet”. 
prawidłową muzyczną deklamację, czyli ścisły związek pomiędzy akcentem muzycznym i akcentem danego słowa" (tłumaczenie - K.P.). Wierność oryginałowi Spaeth (1915: 296-297) wymienia w ostatniej kolejności wśród czynników ważnych podczas tłumaczenia, dając pierwszeństwo odwzorowywaniu dźwięków i tym samym umożliwianiu zaśpiewania przetłumaczonego utworu. Podobne stanowisko reprezentuje Low (2005: 192 ff.), który, formułując swoją zasadę „pentatlonu” w odniesieniu do przekładu piosenek, na pierwszym miejscu stawia możliwość zaśpiewania tekstu docelowego, a w dalszej kolejności oddanie znaczenia słów, naturalności języka, rytmu i rymów.

Opisane powyżej zasady w tłumaczeniu piosenek można porównać także $\mathrm{z}$ hierarchią priorytetów $\mathrm{w}$ procesie tłumaczeniowym komedii telewizyjnych, którą proponuje Zabalbeascoa (1994: 91 ff.) i zgodnie z którą znaczenie dosłowne dialogów nie jest tak ważne, jak funkcja humorystyczna danej wypowiedzi. Wydaje się zatem, że jeśli postaci wykonują jakieś piosenki o zabawnej treści, tłumacz powinien spróbować przełożyć te teksty dowcipnie i w taki sposób, żeby widz mógł w głowie śpiewać je do słyszanej muzyki, i tym samym oddać charakter oryginału i spotęgować efekt humorystyczny przekładu.

\section{Analiza przykładów}

Poniżej zostanie przeanalizowanych sześć przykładów, których celem jest zarysowanie szerokiego zagadnienia, jakim są piosenki w sitcomach. Połowa stanowi samodzielne modyfikacje znanych utworów, a połowa - nawiązania do piosenek, które pojawiły się w dialogach.

\subsection{Modyfikacje znanych piosenek}

Pierwszy przykład modyfikacji został zaczerpnięty z serialu „Przyjaciele”.

Przykład 1: Friends „The One Where Ross Moves in” $(5 \times 07)^{7}$

\begin{tabular}{|c|c|c|}
\hline Tekst wyjściowy EN & $\begin{array}{c}\text { Tekst docelowy PL } \\
\text { lektor }\end{array}$ & $\begin{array}{c}\text { Tekst docelowy DE } \\
\text { dubbing }\end{array}$ \\
\hline $\begin{array}{c}\text { We will - we will - call you } \\
\text { back. }\end{array}$ & $\begin{array}{c}\text { Oddzwo-oddzwo- oddz- } \\
\text { wonimy. }\end{array}$ & $\begin{array}{c}\text { Wir wer-den zu-rück-ruf- } \\
\text { en. }\end{array}$ \\
\hline
\end{tabular}

7 Wszystkie dane bibliograficzne dotyczące analizowanych dialogów oryginalnych oraz ich przekładów są umieszczone w bibliografii na końcu artykułu. 
Jest to modyfikacja tekstu piosenki zespołu Queen pt. „We will rock you”. Analizowany fragment został użyty jako powitanie nagrane na automatycznej sekretarce. W tle można usłyszeć klaskanie wyznaczające rytm charakterystyczny dla tego przeboju. W wersji anglojęzycznej zmieniona została jedynie końcówka wersu. Słowa „rock you” zastąpione zostały frazą „call you back”. Efekt humorystyczny bazuje tu $\mathrm{w}$ dużej mierze na elemencie zaskoczenia, o którym pisał Smith (por. pkt. 1). Liczba sylab modyfikacji nie pokrywa się $\mathrm{z}$ oryginałem, mimo to nie ma żadnej wątpliwości do jakiej piosenki nawiązuje to nagranie. Polska tłumaczka oddała tę aluzję, wydzielając dwie pierwsze sylaby czasownika „oddzwonimy” i powtarzając je dwukrotnie. Oryginalna ścieżka dźwiękowa oraz taka forma tego słowa idealnie odwzorowują efekt anglojęzycznego tekstu. W niemieckiej wersji nie ma żadnego powtórzenia. Zamiast tego zdanie "wir werden zurückrufen” zostało przesylabizowane w rytmie wyznaczanym przez klaskanie i dzięki temu także oddaje humorystyczną modyfikację oryginału.

Modyfikacje stanowią również trzy fragmenty $\mathrm{z}$ odcinka $8 \times 04$ serialu „Jak poznałem waszą matkę".

Przykład 2: How I Met Your Mother „Who Wants to Be a Godparent?” (8×04)

\begin{tabular}{|l|l|l|l|}
\hline \multicolumn{1}{|c|}{ Tekst wyjściowy EN } & \multicolumn{1}{|c|}{$\begin{array}{c}\text { Tekst docelowy PL } \\
\text { lektor }\end{array}$} & \multicolumn{1}{c|}{$\begin{array}{c}\text { Tekst docelowy DE } \\
\text { dubbing }\end{array}$} \\
\hline $\begin{array}{l}\text { Bro MacDonald had } \\
\text { a farm, } \\
\text { E-I-E-I-bro } \\
\text { And on that farm } \\
\text { he had some chicks } \\
\text { E-I-E-I-bro } \\
\text { With a hot chick here } \\
\text { and a dumb chick there... }\end{array}$ & & $\begin{array}{l}\text { Bro MacDonald hat 'ne } \\
\text { Farm, } \\
\text { E-I-E-I-bro } \\
\text { Und auf der Farm da hat er } \\
\text { paar Hühner, } \\
\text { E-I-E-I-bro } \\
\text { Mit 'nem scharfen Huhn } \\
\text { hier und 'nem dummen } \\
\text { Huhn da... }\end{array}$ \\
\hline b) & [brak tłumaczenia] \\
Bro, bro, bro your broat & $\begin{array}{l}\text { Gently to the bar } \\
\text { Hit on sluts, } \\
\text { then do ten shots and... }\end{array}$ & $\begin{array}{l}\text { Bro, bro, paddle mit dem } \\
\text { Boot, } \\
\text { ganz schnell hinüber zur } \\
\text { Bar, } \\
\text { Säufst du dich voll, dann } \\
\text { sind die Bräute toll... }\end{array}$ \\
\hline
\end{tabular}

${ }^{8}$ Bardzo podobny zabieg zastosowano w odcinku $9 \times 03 \mathrm{w}$ „Teorii wielkiego podrywu”, gdzie postaci wystukują znany rytm, śpiewając słowa „We will - we will - percussive shock you”. 
Przykład 2: How I Met Your Mother „Who Wants to Be a Godparent?” (8×04)

\begin{tabular}{|c|c|c|c|}
\hline & Tekst wyjściowy EN & $\begin{array}{c}\text { Tekst docelowy PL } \\
\text { lektor }\end{array}$ & $\begin{array}{c}\text { Tekst docelowy DE } \\
\text { dubbing }\end{array}$ \\
\hline c) & $\begin{array}{l}\text { The boobs on the bus } \\
\text { go up and down } \\
\text { Up and down, up and } \\
\text { down } \\
\text { The boobs on the bus } \\
\text { go up and down } \\
\text { All through the town. }\end{array}$ & [brak tłumaczenia] & $\begin{array}{l}\text { Die Möpse im Bus gehen } \\
\text { rauf und runter, rauf und } \\
\text { runter, rauf und runter. } \\
\text { Die Möpse im Bus gehen } \\
\text { rauf und runter durch die } \\
\text { Stadt ganz munter. }\end{array}$ \\
\hline
\end{tabular}

Każdy z nich bazuje na melodii i tekście znanych dziecięcych piosenek. Są to: a) „Old MacDonald Had a Farm”, b) „Row, Row, Row Your Boat” oraz c) „The Wheels on the Bus”. Nawiązanie do tych utworów podkreślone jest ponadto poprzez kanał wizualny, ponieważ Barney, postać, która je wykonuje, przebrany jest kolejno za farmera, marynarza oraz kierowcę autobusu. Dowcipny charakter tych fragmentów bazuje na zasadzie niespójności (Smith 1999: 14), ponieważ w tekst dziecięcych piosenek zostały wplecione aluzje seksualne'. W polskiej wersji lektorskiej piosenki te zostały całkiem opuszczone. Nie wydaje się to jednak w tym przypadku być dopuszczalnym rozwiązaniem - słysząc śpiew aktora oraz widząc jego przebranie, widz ma świadomość, że został pominięty jakiś złożony żart. Ponieważ odczytanie przetłumaczonego tekstu przez lektora mogłoby zagłuszyć oryginał i wywołać efekt odwrotny od zamierzonego, można by wyjątkowo dodać w tym momencie podpisy. Podobna praktyka stosowana jest podczas piosenek wykonywanych w musicalach. Bazując na dostępnych polskich tłumaczeniach analizowanych piosenek dziecięcych, można stworzyć modyfikacje o takim samym charakterze jak w tym serialu. „Old MacDonald Had a Farm” ma polskie tłumaczenie pt. „Pan MacDonald farmę miał”10, a "The Wheels on the Bus” - „Koła autobusu kręcą się"11. Jedynie piosenka „Row Row Row Your Boat" nie doczekała się jeszcze polskiego przekładu.

W niemieckiej wersji językowej zostały przetłumaczone wszystkie piosenki. W modyfikacjach a) i b) zapożyczony został charakterystyczny dla Barneya leksem bro (pol. 'brachol'). Wprawdzie można przetłumaczyć to słowo na język niemiecki, np. jako Bruder albo Freund, jednak po pierwsze

9 Zgodnie z tą samą zasadą postąpiono w odcinku $4 \times 11$, w którym Barney śpiewa sprośne teksty piosenek na melodię świątecznych utworów: „Jingle Bells”, „We Wish You a Merry Christmas" i „The Dreidel Song”.

${ }_{10}$ Por. http://bajlandia.tv/piosenki-dla-dzieci/pan-macdonald-farme-mial (dostęp: 31 marca 2016 r.).

${ }^{11}$ Por. http://www.krasnale.de/index.php/home/piosenki-i-zabawy (dostęp: 31 marca 2016 r.). 
liczba sylab tych wyrazów różni się od oryginału, co mogłoby utrudnić zaśpiewanie przekładu do odpowiedniej melodii, a po drugie leksem ten przyjął się w wersji niemieckiej serialu. Co się tyczy znaczenia i konotacji analizowanych piosenek, to można zauważyć, że zarówno ekwiwalencja denotatywna, konotatywna, jak i formalno-estetyczna zostały w tłumaczeniu zachowane.

Ostatnia $\mathrm{z}$ analizowanych modyfikacji piosenek pojawiła się $\mathrm{w}$ sitcomie „Teoria wielkiego podrywu”.

Przykład 3: The Big Bang Theory „The Vengeance Formulation” (3×09)

\begin{tabular}{|c|c|c|}
\hline Tekst wyjściowy EN & $\begin{array}{c}\text { Tekst docelowy PL } \\
\text { lektor }\end{array}$ & $\begin{array}{c}\text { Tekst docelowy DE } \\
\text { dubbing }\end{array}$ \\
\hline $\begin{array}{l}\text { Bernadette! } \\
\text { I am so sorry for } \\
\text { Trying to propose to you! } \\
\text { Bernadette! } \\
\text { You found it creepy but } \\
\text { That's just the kind of thing } \\
\text { I do! } \\
\text { I know now it was too soon } \\
\text { to talk of love. } \\
\text { It was just a crazy idea that } \\
\text { came to me in my tub. } \\
\text { But Bernadette, give me } \\
\text { one more chance, sweet } \\
\text { Bernadette! } \\
\text { I'll get the hang of this thing } \\
\text { they call romance, sweet } \\
\text { Bernadette! } \\
\text { I dream to once again kiss } \\
\text { your lips, sweet Bernadette! } \\
\text { Sincerely yours, Howard } \\
\text { Wolowitz! } \\
\text { Bernadette, tell the world } \\
\text { you belong to me! } \\
\text { Tell the world you belong } \\
\text { to me! } \\
\text { Bernadette! } \\
\text { Thank you, Cheesecake } \\
\text { Factory! }\end{array}$ & $\begin{array}{l}\text { Bernadette! } \\
\text { Przepraszam, że się oświad- } \\
\text { czyłem. } \\
\text { Wybacz, że zaufanie twoje } \\
\text { nadużyłem. } \\
\text { Wiem, że za szybko mówi- } \\
\text { łem o miłości } \\
\text { i w wannie chciałem cię } \\
\text { ugościć. } \\
\text { Daj mi szansę, o słodka } \\
\text { Bernadette! } \\
\text { Wiem, co zrobić, byś poczu- } \\
\text { ła miłości zew! } \\
\text { Marzę, by się przytulić do } \\
\text { twoich lic! } \\
\text { Twój na zawsze, Howard } \\
\text { Wolowitz } \\
\text { Dziękuję, Cheesecake } \\
\text { Factory }\end{array}$ & $\begin{array}{c}\text { [brak tłumaczenia] } \\
\text { Danke, Cheesecake Factory! }\end{array}$ \\
\hline
\end{tabular}

Bazuje ona luźno na utworze „Bernadette” zespołu Four Tops. Z oryginału zaczerpnięte zostało zdanie "tell the world you belong to me" oraz imię żeńskie Bernadette, ponieważ jest równocześnie imieniem jednej z bohaterek. Pozostała część tekstu opisuje kłótnię pomiędzy Howardem, postacią, która śpiewa tę piosenkę, a jego dziewczyną, Bernadette. Komizm tego wy- 
konania polega na osobliwej treści przeprosin i przechodzeniu w falset przy słowach „sweet Bernadette”. Ponadto z jednej strony całemu tekstowi została niejako nadana forma listu (na początku widnieje zwrot do adresata: Bernadette, a pod koniec formalny podpis nadawcy: „Sincerely yours, Howard Wolowitz" (pol. 'Z poważaniem, Howard Wolowitz'), a z drugiej - Howard wieńczy swój występ pożegnaniem z publicznością, jak muzyk na koncercie: „Thank you, Cheesecake Factory!” (pol. 'Dziękuję, Cheesecake Factory'²!'). Takie zestawienie różnych rejestrów języka również ma na celu stworzenie efektu humorystycznego (por. Tomaszkiewicz 2006: 189-190) i ponownie odnosi się do zasady niespójności (Smith 1999: 14). W polskim tłumaczeniu została oddana niekonwencjonalna treść przeprosin. Choć odbiega ona od denotytawnego znaczenia oryginału, idealnie aktywizuje skojarzenia konotatywne. Forma tekstu także została zachowana: całość zaczyna się od zwrotu do Bernadette („Bernadette!”), zawiera pożegnanie z publicznością („Dziękuję, Cheesecake Factory!”) oraz podpis nadawcy („Twój na zawsze, Howard Wolowitz"). W tym przypadku jest to jednak podpis charakterystyczny dla listu miłosnego, nie dla listu formalnego. Tłumacz zrezygnował, więc z łączenia różnych rejestrów języka. Za to dodane zostały rymy parzyste, które odróżniają omawiany fragment od pozostałych dialogów, wywołują skojarzenie z tekstami piosenek i wzmacniają efekt humorystyczny całości.

W niemieckiej wersji językowej analizowany fragment został pominięty. Jedynie pożegnanie z publicznością zostało przetłumaczone. Jest to zaskakujące rozwiązanie, ponieważ $\mathrm{w}$ wersji dubbingowej nie powinny występować luki tłumaczeniowe. Ponadto dla niemieckojęzycznych widzów głos Howarda to głos aktora dubbingowego, a nie oryginalnego odtwórcy, Simona Helberga. Ponieważ celem wykonania tego utworu było rozbawienie widzów, tekst piosenki powinien zostać przetłumaczony i zdubbingowany. Nie mamy tu bowiem do czynienia $\mathrm{z}$ operą czy musicalem, w których śpiew jest kluczowym elementem i w których zachowanie głosu oryginału ma na celu umożliwienie widzom pełnego doświadczenia kunsztu wykonawców.

\subsection{Nawiązania do piosenek $w$ dialogach}

Druga połowa przykładów przedstawia nawiązania do piosenek zawarte w dialogach. Pierwsze nawiązanie, występujące w serialu „Przyjaciele”, składa się z dwóch części.

12 Nazwa restauracji, w której pracują dwie główne bohaterki. 
Przykład 4: Friends „The One with Ross's Wedding” (4×23/24)

\begin{tabular}{|c|c|c|}
\hline Tekst wyjściowy EN & $\begin{array}{c}\text { Tekst docelowy PL } \\
\text { lektor }\end{array}$ & $\begin{array}{c}\text { Tekst docelowy DE } \\
\text { dubbing }\end{array}$ \\
\hline $\begin{array}{l}\text { TV: Where everybody } \\
\text { knows your name } \\
\text { And they're always glad you } \\
\text { came } \\
\text { You wanna be where you } \\
\text { can see } \\
\text { The troubles are all the same } \\
\text { You wanna be } \\
\text { Where everybody knows } \\
\text { your name }\end{array}$ & [brak tłumaczenia] & [brak tłumaczenia] \\
\hline $\begin{array}{l}\text { JOEY: I first met Ross in } \\
\text { this coffeehouse back home. } \\
\text { Home. New York City. } \\
\text { Where everybody knows } \\
\text { my name. Uh, anyway...uh, } \\
\text { I love you guys. But not as } \\
\text { much as I love America. }\end{array}$ & $\begin{array}{l}\text { J: Poznałem Rossa w kawiar- } \\
\text { ni, u nas... U nas... W No- } \\
\text { wym Jorku, gdzie wszyscy } \\
\text { mnie znają. Tak czy inaczej, } \\
\text { kocham was, ale nie tak jak } \\
\text { Amerykę. }\end{array}$ & $\begin{array}{l}\text { J: Das erste Mal habe ich } \\
\text { Ross in unserem Stammcafé } \\
\text { getroffen... Wo ich zu Hause } \\
\text { bin. In New York City. Dort, } \\
\text { wo alle Menschen meinen } \\
\text { Namen kennen. Wie dem } \\
\text { auch sei, ich liebe euch zwei. } \\
\text { Aber Amerika liebe ich noch } \\
\text { viel mehr, jawohl! }\end{array}$ \\
\hline
\end{tabular}

Najpierw pojawia się scena, w której Joey ogląda w Londynie telewizję i początkowo cieszy się, gdy rozpoczyna się czołówka amerykańskiego sitcomu „Cheers” (polski tytuł „Zdrówko”), ale po chwili smutnieje, ponieważ uświadamia sobie swoją tęsknotę za Nowym Jorkiem. Tekst piosenki przewodniej „Where Everybody Knows Your Name” Gary’ego Portnoya podkreśla nostalgię Joeya. Następnie Joey wplata te słowa w swój toast podczas kolacji, co kryje w sobie pewną niespójność tematyczną. Zarówno w polskiej, jak i w niemieckiej wersji językowej pierwsze wystąpienie tej piosenki zostało opuszczone. Widz słyszy wprawdzie oryginalną ścieżkę dźwiękową, ale o ile nie zna języka angielskiego, to może nie zrozumieć, z czego wynika zmiana nastroju Joeya. W drugiej części tłumacze przełożyli ten cytat dosłownie i w samej przemowie tęsknota bohatera jest już jednoznaczna. Wydaje się jednak, że to samo tłumaczenie mogło pojawić się w pierwszym przypadku, np. w formie podpisów na ekranie (zarówno w wersji niemieckiej, jak i polskiej), żeby bardziej podkreślić emocje Joeya. Lektor mógłby także odczytać przekład całej piosenki, ponieważ nawet jeśli by zagłuszył oryginał, to tekst utworu odgrywał tu ważniejszą rolę niż śpiew piosenkarza.

Drugi przykład tego typu z tego samego sitcomu pochodzi z odcinka, w którym jest mowa o koncercie Stinga. 
Przykład 5: Friends „The One With Monica’s Boots” $(8 \times 10)$

\begin{tabular}{|c|c|c|}
\hline Tekst wyjściowy EN & $\begin{array}{l}\text { Tekst docelowy PL } \\
\text { lektor }\end{array}$ & $\begin{array}{l}\text { Tekst docelowy DE } \\
\text { dubbing }\end{array}$ \\
\hline $\begin{array}{l}\text { PHOEBE: Please get the } \\
\text { tickets. } \\
\text { ROSS: I just can't do it. }\end{array}$ & $\begin{array}{l}\text { PH: Proszę, załatw bilety. } \\
\text { R: Przykro mi, nie mogę. }\end{array}$ & $\begin{array}{l}\text { PH: Bitte, besorg doch die } \\
\text { Karten, Ross. } \\
\text { R: Es tut mir wirklich leid, } \\
\text { Phoebe. Ich kann da gar } \\
\text { nichts tun. }\end{array}$ \\
\hline $\begin{array}{l}\text { PHOEBE: Yes, you can. } \\
\text { Sting says so himself. } \\
\text { ROSS: What? } \\
\text { PHOEBE: Ross can... } \\
\text { ROSS: Look, I'm sorry... }\end{array}$ & $\begin{array}{l}\text { PH: Możesz. Sting sam to } \\
\text { powiedział. } \\
\text { R: Co? } \\
\text { PH: Ross może... } \\
\text { R: Niestety... }\end{array}$ & $\begin{array}{l}\text { PH: Doch, das kannst du. } \\
\text { Sting hat es doch selbst } \\
\text { gesagt. } \\
\text { R: Was? } \\
\text { PH: Ross can... }\end{array}$ \\
\hline $\begin{array}{l}\text { PHOEBE: Ross can... } \\
\text { ROSS: Phoebe... } \\
\text { PHOEBE: Ross can get me } \\
\text { the tickets, Ross can get me } \\
\text { the tickets! }\end{array}$ & $\begin{array}{l}\text { [brak] } \\
\text { [brak] } \\
\text { PH: Ross może. Dawaj } \\
\text { bilety! [brak] }\end{array}$ & $\begin{array}{l}\text { R: Hör zu, Phoebe. Es tut } \\
\text { mir leid, es geht wirklich... } \\
\text { PH: Ross can... } \\
\text { R: Phoebe... } \\
\text { PH: Ross can... Er besorgt } \\
\text { die Karten, Ross can... Er } \\
\text { besorgt die Karten. }\end{array}$ \\
\hline $\begin{array}{l}\text { ROSS: You're gonna love me } \\
\text { so much. I got Sting tickets! }\end{array}$ & $\begin{array}{l}\text { R: Będziesz mnie uwielbiać! } \\
\text { Mam bilety na Stinga! }\end{array}$ & $\begin{array}{l}\text { R: Du wirst mich bewun- } \\
\text { dern noch mehr als sonst! } \\
\text { Sieh dir das an: Ich habe } \\
\text { Sting Karten! }\end{array}$ \\
\hline $\begin{array}{l}\text { PHOEBE: Oh, my God, I do } \\
\text { love you! How did you do it? }\end{array}$ & $\begin{array}{l}\mathrm{PH}: \text { Kocham cię! Jak to } \\
\text { zrobiłeś? }\end{array}$ & $\begin{array}{l}\text { PH: Oh, mein Gott, ich be- } \\
\text { wundere dich wirklich! Wie } \\
\text { hast du das hingekriegt? }\end{array}$ \\
\hline $\begin{array}{l}\text { ROSS: Well, let's just say: } \\
\text { Ross can... }\end{array}$ & R: Ross potrafi... & $\begin{array}{l}\text { R: Weißt du, ich werde es } \\
\text { mal so sagen: Ross can... }\end{array}$ \\
\hline
\end{tabular}

Phoebe bardzo zależy, żeby pójść na ten występ, a Ross ma możliwość poproszenia o bilety samego artystę. Aby bardziej zmotywować przyjaciela, Phoebe śpiewa a capella słowa "Ross can” na melodię piosenki "Roxanne” zespołu The Police, co można postrzegać zarówno w kontekście zaskoczenia, jak i zwięzłości w ujęciu Smitha (1999: 15, 17-18). W języku angielskim imię żeńskie Roxanne i syntagma „Ross can” mają prawie identyczną wymowę różnią się kolejnością głosek /s/ i /k/. Ponieważ użyte wyrazy stanowią jednocześnie podmiot i orzeczenie, mogły one bez problemu zostać włączone do zdania „Ross can get me the tickets” (pol. 'Ross może załatwić mi bilety'). W polskiej wersji analizowana syntagma przetłumaczona została trzy z pięciu razy. Opuszczono powtórzenia identycznych konstrukcji, co jest powszechnie stosowaną techniką w wersji lektorskiej ${ }^{13}$. Tłumaczenie „Ross może” nie

13 Tomaszkiewicz (2006: 119) wymienia wśród pomijanych elementów w wersji lektorskiej, 
jest podobne do imienia „Roxanne” oraz przewyższa je liczbą sylab. Większy problem stanowi jednak brak rozbudowania analizowanej syntagmy do dłuższego zdania oraz brak konsekwencji w tłumaczeniu. Na koniec pierwszej wypowiedzi dodane zostało odrębne zdanie w trybie rozkazującym, choć można by rozszerzyć zaproponowane tłumaczenie do zdania „Ross może załatwić (mi) bilety". Spójne i konsekwentne tłumaczenie lepiej oddałoby charakter oryginału.

Niemiecka tłumaczka zapożyczyła oryginalną modyfikację do swojego tekstu. Jest to zaskakujące rozwiązanie, ponieważ niemieckojęzyczna wersja jest wersją dubbingowaną, więc oryginalne dialogi są w pełni zastępowane tłumaczeniem, a kwestie dialogowe odczytywane przez aktorów, którzy mają swobodę grania głosem (w przeciwieństwie do lektora) (por. Tomaszkiewicz 2006: 116; Díaz Cintas/Orero 2010: 441). Ponadto niemieckim ekwiwalentem odpowiadającym słowom „Ross can” jest „Ross kann”. Syntagma ma taką samą liczbę sylab jak oryginał i w niewielkim stopniu różni się wymową (w wersji anglojęzycznej występuje samogłoska /æ/, w wersji niemieckojęzycznej - /a/). Mimo że takie tłumaczenie bardziej odbiega od imienia „Roxanne", to zaintonowanie odpowiedniej melodii oraz kontekst dialogu wyraźnie wskazują na to, do jakiej piosenki jest to nawiązanie. Zastosowanie niemieckiego ekwiwalentu umożliwiłoby także stworzenie rozbudowanego zdania na koniec pierwszego fragmentu. Mogłoby ono brzmieć: „Ross kann mir die Karten besorgen".

Ostatni przykład pochodzi z serialu „Jak poznałem waszą matkę" i pojawia się w rozmowie, w której Robin opowiada pozostałym bohaterom o swoim pierwszym chłopaku.

Przykład 6: How I Met Your Mother „Sandcastles in the Sand” (3×16)

\begin{tabular}{|l|l|l|}
\hline \multicolumn{1}{|c|}{ Tekst wyjściowy EN } & \multicolumn{1}{|c|}{$\begin{array}{c}\text { Tekst docelowy PL } \\
\text { lektor }\end{array}$} & \multicolumn{1}{c|}{$\begin{array}{c}\text { Tekst docelowy DE } \\
\text { dubbing }\end{array}$} \\
\hline $\begin{array}{l}\text { ROBIN: Simon. I thought } \\
\text { he was the coolest guy ever. } \\
{[\ldots] \text { We spent the whole }} \\
\text { summer madly in love. }\end{array}$ & $\begin{array}{l}\text { R: Sądziłam, że Simon jest } \\
\text { najwspanialszym chłopa- } \\
\text { kiem na świecie. [...] To } \\
\text { było lato szalonej miłości. }\end{array}$ & $\begin{array}{l}\text { R: Simon. Ich hielt ihn da- } \\
\text { mals für den coolsten Typen } \\
\text { aller Zeiten. [...] Wir waren } \\
\text { einen ganzen Sommer lang } \\
\text { irrsinnig verliebt. } \\
\text { B: Tell me more. Tell me } \\
\text { more. Like, did he have } \\
\text { a car? }\end{array}$ \\
$\begin{array}{l}\text { Tell me more. Like, did he } \\
\text { have a car? }\end{array}$ & $\begin{array}{l}\text { B: Powiedz coś jeszcze. } \\
\text { Miał może samochód? }\end{array}$ & \multicolumn{2}{|l}{} \\
\hline
\end{tabular}

„wszelkiego typu powtórzenia o charakterze ekspresywnym [...]” oraz „Zdania niedokończone [...]". 
W swoim opisie dziewczyna podkreśla perfumy Simona, jego kolekcję koszulek oraz umiejętne jeżdżenie na deskorolce, brzmi więc bardzo dziecinnie jak na swój wiek. W oryginale Barney recytuje prześmiewczo fragment piosenki „Summer nights” z musicalu „Grease”, w której dwie postaci opowiadają o swojej wakacyjnej miłości. W polskim tłumaczeniu nie ma ani nawiązania do piosenki, ani złośliwości Barneya. Jest to raczej grzeczne pytanie. Nie została zatem spełniona funkcja tej aluzji. Tłumacz mógł sięgnąć po fragment polskiego przekładu musicalu Grease. Wersja polska stworzona przez Agnieszkę Rostkowską dla HBO Polska brzmi „Powiedz, własną brykę miał?”, a wersja teatralna w przekładzie Andrzeja Ozgi „No i co? No i co? Czy on wóz jakiś miał?"14. Ponieważ drugi z przekładów pasuje do muzyki, osoby znające musical mogłyby skojarzyć te słowa z oryginałem. Powtórzenie wzmocniłoby także efekt humorystyczny, ponieważ sugerowałoby, że Barney udaje zainteresowanie i kpi sobie z opowieści Robin. Jednak w tłumaczeniu nie musiało wcale zostać zachowane nawiązanie do musicalu. Funkcją aluzji, jak już wspomniano, było naśmiewanie się z opisu ukochanego Robin. Tłumaczenie mogłoby zatem stanowić po prostu żart z młodzieńczej miłości i zawierać pytanie o kolejną cechę charakterystyczną Simona, np. „A stawiał włosy na żel?". Taki przekład oddałby w pełni cel komunikacyjny wypowiedzi Barneya.

W niemieckiej wersji oryginalny cytat jest odczytany przez aktora dubbingowego. Tłumacz zadbał więc o zachowanie nawiązania. Także w tym przypadku można było się pokusić o większą ingerencję w tekst i bardziej skupić się na oddaniu funkcji humorystycznej, a nie oddaniu zabarwienia kulturowego.

\section{Wnioski}

Przytoczone przykłady pokazują, jak mogą wyglądać nawiązania do piosenek i modyfikacje znanych utworów w sitcomach. Wszystkie zanalizowane fragmenty pełniły funkcję humorystyczną i opuszczenie tych tekstów w tłumaczeniu pozbawiłoby dane odcinki najważniejszej cechy sitcomu - komizmu. Jak pokazała powyższa analiza, nie ma jednej techniki, którą można zastosować w przekładzie modyfikacji i nawiązań o takim charakterze. Różne techniki stosowane są w zależności od tego, czy w tle słychać melodię lub

${ }^{14} \mathrm{http}: / /$ www.polskastacja.pl/tekst,piosenki,Teatr+Roma+-+Letnia+Noc (dostęp: 31 marca 2016 r.). 
podkład dźwiękowy (por. przykład 1, 2, 3, 5) lub od tego, czy kanał wizualny obrazuje dany utwór muzyczny (por. przykład 2). Przykłady 2 i 6 pokazały, że dobre tłumaczenie aluzji bądź modyfikacji można oprzeć na istniejącym przekładzie danego utworu. Z przykładu 5 wynika, że bardzo ważna w tłumaczeniu jest spójność i konsekwencja. Na podstawie przykładów 3 i 6 można także wykazać, że nie zawsze denotatywne znaczenie modyfikacji/nawiązania jest najważniejsze - czasem efekt humorystyczny można uzyskać przy pomocy innych słów czy środków. Wydaje się, że bardziej udane były tłumaczenia, które albo były dostosowane do muzyki i tym samym możliwe do zaśpiewania (por. przykład 1, 2, 5), albo którym nadano formę kojarzącą się z piosenką (por. przykład 3). Zarówno w wersji lektorskiej, jak i w wersji z dubbingiem, możliwe jest wyświetlenie podpisów z tłumaczeniem, gdy tłumacz uzna, że oryginalny śpiew aktora powinien być zachowany, tak jak ma to miejsce w musicalach. Jednak przykład 3 pokazuje, że przy dobrym tłumaczeniu nawet głos lektora nie zakłóci efektu humorystycznego całości.

Przeprowadzona analiza stanowi jedynie namiastkę problematyki tłumaczenia piosenek $\mathrm{w}$ amerykańskich sitcomach. Jak dowodzono na początku artykułu, piosenki pojawiają się w tym gatunku bardzo często w przeróżnych formach: w wersji oryginalnej, zmodyfikowanej, w postaci coveru, nawiązania, a także nowego utworu. Choć tłumaczenie tekstów piosenek w utworach audiowizualnych kojarzy się głównie z musicalami, to jednak trzeba mieć na uwadze fakt, że jest ono także nieuniknione w tłumaczeniu sitcomów. Piosenki te wywołują efekt humorystyczny w oryginale. Tłumacz musi zatem zmierzyć się z dwoma aspektami w przekładzie: zarówno z tłumaczeniem piosenek, jak i z oddaniem humoru.

\section{Literatura}

\section{Źródła}

Friends: The One with Ross's Wedding (07.05.1998). Scenariusz oryginalny: M. Borkow, Sh. Goldberg-Meehan, S. Silveri. Wersja niemiecka: J. Richter. Wersja polska: M. Kwiatkowski.

Friends: The One Where Ross Moves in. (12.11.1998). Scenariusz oryginalny: G. McCreery, P. Rein. Wersja niemiecka: J.Richter. Wersja polska: I. Iwańska.

Friends: The One With Monica's Boots. (06.12.2001). Scenariusz oryginalny: R. Carlock, B. Buckner, \& S. Jones. Wersja niemiecka: J.Richter. Wersja polska: E. Stochwicz. 
How I Met Your Mother: Sandcastles in the Sand. (21.04.2008). Scenariusz oryginalny: Kourtney Kang. Wersja niemiecka: Ch. Langhagen, N. Steinke. Wersja polska: J. Mikina.

How I Met Your Mother: Who Wants to Be a Godparent?. (15.10.2012). Scenariusz oryginalny: M. Kuhn. Wersja niemiecka: Ch. Langhagen, N. Steinke. Wersja polska: brak danych, na zlecenie: Comedy Central Polska Synthesis Media.

Grease. (brak danych). Wersja polska: A. Rostkowska.

The Big Bang Theory: The Vengeance Formulation. (23.11.2009). Scenariusz oryginalny: R. Rosenstock, J. Reynolds, \& S. Holland. Wersja niemiecka: S. Ludwig. Wersja polska: R. Nosek.

\section{Literatura przedmiotowa}

Chiaro, D., 1992, The Language of Jokes: Analysing Verbal Play. London / New York.

Díaz Cintas, J. \& Orero, P., 2010, „Voiceover and dubbing”, [w:] Handbook of translation studies. Volume 1, red. Y. Gambier, L. Van Doorslaer, Amsterdam / Philadelphia, s. 441-445.

Dore, M., 2008, The Audiovisual Translation of Humour: Dubbing the First Series of the TV Comedy Programme Friends into Italian, rozprawa doktorska, URL: https://www.academia.edu/16946977/MD_PHD_THESIS_The_Audiovisual_Translation_of_Humour_Dubbing_the_First_ Series_of_the_TV_Comedy_Programme_Friends_into_Italian (dostęp: 7 października 2017 r.).

Döring, S., 2006, Kulturspezifika im Film: Probleme ihrer Translation (TRANSÜD. Arbeiten zur Theorie und Praxis des Übersetzens und Dolmetschens. $B d$. 10). Berlin.

Kalaga, W., 1997, „Komizm a przekładalność”, [w:] Studia o przekładzie. Komizm a przekład, red. P. Fast, Katowice, s. 9-18.

Koller, W., 2004, Einführung in die Übersetzungswissenschaft. Wiesbaden.

Low, P., 2005, „The Pentathlon Approach to Translating Songs”, [w:] Song and Significance: Virtues and Vices of Vocal Translation, red. D. L. Gorlée, Amsterdan / New York, s. 185-212.

Mills, B., 2009, The Sitcom, Edinburgh.

Mintz, L. E., 1985, „Situation Comedy”, [w:] Television Genres: A Handbook and Reference Guide, red. B. G. Rose, Westport, s. 107-129.

Raphaelson-West, D. S., 1989, „On the Feasibility and Strategies of Translating Humor", [w:] Meta. Volume 34, Number 1, s. 128-141, URL: http:// www. erudit.org/revue/meta/1989/v34/n1/003913ar.pdf (dostęp: 23 kwiet- 
nia 2016 r.).

Savorelli, A., 2010, Beyond Sitcom: New Directions in American Television Comedy, Jefferson et al.

Smith, E. S., 1999, Writing Television Sitcoms, New York.

Spaeth, S., 1915, „Translating to Music”, [w:] The Musical Quarterly. Vol. 1, No. 2 (Apr., 1915), s. 291-298, Oxford, URL: http://www.jstor.org/stable/737851 (dostęp: 24 marca 2016 r.).

Tomaszkiewicz, T., 2004, Terminologia tłumaczenia, Poznań.

Tomaszkiewicz, T., 2006, Tłumaczenie audiowizualne, Warszawa.

Zabalbeascoa, P., 1994, „Factors in dubbing television comedy”, [w:] Perspectives: Studies in Translatology, 2(1), s. 89-99.

\section{Źródła internetowe}

URL: http://bajlandia.tv/piosenki-dla-dzieci/pan-macdonald-farme-mial (dostęp: 31 marca 2016 r.).

URL: http://www.krasnale.de/index.php/home/piosenki-i-zabawy (dostęp: 31 marca 2016 r.).

URL: http://www.polskastacja.pl/tekst,piosenki,Teatr+Roma+-+Letnia+Noc (dostęp: 31 marca 2016 r.).

URL: https://sjp.pwn.pl/szukaj/humor.html (dostęp: 31 marca 2016 r.).

URL: https://sjp.pwn.pl/szukaj/zabawny.html (dostęp: 31 marca 2016 r.).

\section{Translating American sitcoms: songs as a challenge for the translator Summary}

The object of this analysis is the role of songs in American sitcoms and potential translation difficulties with translating song modifications and references to famous lyrics in this genre. The first step of the research was to prove that songs are a recurring element in many American sitcoms. In order to do that, dialogues of six different series were analysed. Next, three different examples of song modifications sung by actors and three verbal references to famous song lyrics were chosen as to illustrate the kind of musical-verbal elements that translators have to face while translating sitcoms. The theoretical part of the paper is devoted to sitcom as a text genre and general aspects of song translation. What follows is an analysis of specific examples taken from Friends, The Big Bang Theory, How I Met Your Mother, and their official TV translations into Polish and German. It has been shown that songs in sitcoms function not only as a musical element, but also as a joke. Moreover, it has been demonstrated that different translation techniques can be used while translating lyrics in sitcoms. There are various aspects that have to be taken into consideration, such as 
music in the background or references to the lyrics presented visually on the screen. The results indicate that it is essential for the translator to be consistent and sometimes to favour the humorous function of the source text over its denotative meaning. The 'singability' and song-like form of the target-language lyrics seem also to be of great importance in the reception of translation.

Keywords: audiovisual translation, sitcom, translation of humour, songs in films



